\title{
Bir Medcezir Manzarası: Türkiye'de Laiklik (1928-1948)
}

\author{
Arş. Gör. Murat KARATAŞ*
}

\section{$\ddot{O Z Z E T}$}

Bu makale, Türkiye Cumhuriyeti'nin kurulma aşaması ile başlayan Laiklik fikriyatının, 1937 yılında son şeklini alan Laiklik Devrimi'ne dönüşmesi ve Atatürk'ün vefatı sonrası algılanışı üzerinde durmaktadır. Nitekim bu algılanışta içsel olarak çok partili hayata geçişin, dişsal olarak ise Soğuk Savaş ortamının büyük etkisi olduğu görülmektedir. Bu iki ana etken ekseninde, henüz on yıl kadar yetersiz bir zamanın geçmesine ră̆men, devrimlerin yerleştĭ̆i iyimserliği gösterilmiştir. Özellikle 1940'll yıllarda Laiklik, 1928-1938 yılları ile kıyasladığımızda, seçim-iktidar sorunu, dış gelişmeler-ekonomik buhran gibi temel etkenlerin aktarımıyla dură̆anlaşmış, hatta gerilemiştir.

Çă̆daşlaşma amacının en önemli dayană̆ olan Laiklik devrimi, ulusal gereklerin doğurduğu anlayıştan, evrensel anlayışa yönelerek iç dinamiklerini yitirmiş, pasifleşmiştir. Mustafa Kemal Atatürk'ün deyimi ile “Türk milleti ve bir de milletler tarihinin bin bir facia ve ızdırap kaydeden yapraklarından çıkardı ğımız netice”lerle yapllan Türk Devrimleri, özellikle Laiklik, Atatürk'ün ölümünden kısa bir süre sonra tahrip edilmeye başlanmıs; ardından siyasi arena "Din Oyunu Aktörleri” ne açılmıştır.

\begin{abstract}
This article focuses on the process in which the idea of Secularism that started with the foundation of the Republic of Turkey turned into the Secularism reform in 1937 and how it was perceived after the death of Atatürk. As a matter of fact, it can be seen that this perception was effected domestically by the commencing of the multi-party system while internationally by the Cold War environment. Under the scope of these two main factors, it was optimistically believed that the reforms were
\end{abstract}

* Çanakkale Onsekiz Mart Üniversitesi, Fen-Edebiyat Fakültesi, Tarih Bölümü, Araştırma Görevlisi. 
settled event though only an insufficient time of ten years have passed. Especially in the 40's, when compared to the period between 1928-1938, secularism entered into a stationary state, even receded, with the effect of basic factors such as international events and economical crisis.

Secularism reform, which was the most important basis of the goal to become modern, lost its internal dynamics and became passive by heading towards a universal approach instead of an approach that is necessitated by local requirements. Turkish reforms, especially secularism, "which were created by the Turkish nation and as a result of the conclusions we have reached during our catastrophic and painful journey in the history of nations", as Atatürk puts it, started to be destructed after the death of Ataturk and then became the stage of the "Actors of the Religion Play" in the middle of the political scene.

\section{GİRIŞ}

Osmanlı Devleti'nin özellikle Meşrutiyet devrinde, din-devlet ilişkilerinin neticeleri küçük bir çevre tarafından da olsa anlaşılmıştır; fakat Osmanlı toplumunun henüz hazır olmadığı ve sultanların aynı zamanda İslam dünyasının halifesi olması nedeniyle koyulacak kanunların, memlekette ve İslam dünyasında dini hislere kayıtsız kalındığı izlenimini uyandırmamak düşüncesi ile siyasi, sosyal, ekonomik, askeri, eğitim gibi birçok alanda ikiliğe gidilme yolu izlenmiştir. ${ }^{1} \mathrm{Bu}$ ikiliğin bir başka nedeni de Osmanlı Devleti’nin aydınlanmayı yaşamakta olan zihniyete ${ }^{2}$, ümmet dönemini aşarak uluslardan oluşan yapıya ve sanayi uygarlığını başlatmış bir topluma erişmemiş olma durumudur. ${ }^{3}$ Lakin, bu son dönemde yaşanan birçok sorun neticesinde ortaya çıkan bazı pratik fikirler, Cumhuriyet dönemi çağdaşlaşma atılımlarının nüvesini oluşturmuştur.

Birinci Dünya Savaşı sonrası, Osmanlı Devleti'nin Batı'ya tamamen teslim olmasının ardından kurulan Ankara Hükümeti, hem Batı'ya hem de Milli Mücadele aleyhtarı Osmanlı Devleti'ne karşı zafer kazanmıştır. Daha Milli Mücadele'nin başlangıcından itibaren yerleşen "Milli Hâkimiyet" kavramı, "teokratik devlet" yerine "ulusal devlet” görüşünün temellerini atmıştır. Buna göre millet, devlet yönetiminde kendi iradesini ilan etmiştir.

' Ömer Lütfi Barkan, "Türkiye'de Din ve Devlet İlişkileri”, Cumhuriyetin 50. Yıldönümü Semineri, Türk Tarih Kurumu Yayını, Ankara 1975, s. 93-94; Niyazi Berkes, Türkiye'de Çağdaşlaşma, 2. Baskı, Yay. Haz. Ahmet Kumaş, Yapı Kredi Yayınları, İstanbul 2002, s. 439-444.

${ }^{2}$ Macit Gökberk, 17-18. yüzyıl aydınlanmasının din anlayışını 'akıl dini', 'doğal din' olarak; akıl dinini ise, "akılda bulunmuş olan, aklın yattığ nitelendirmiştir. Bkz. Macit Gökberk, Felsefe Tarihi, 17. Baskı, Bilgi Kitabevi, İstanbul 2007, s. 321 .

3 Metin Heper, "Aydınlanma Felsefesi, Devrimler ve Atatürk”, Çağdaş Düşüncenin Işı̆̆ında Atatüirk, 2. Baskı, Dr. Nejat F. Eczacıbaşı Vakfı Yayınları, İstanbul 1986, s. 298. 
$\mathrm{Bu}$ irade, başlangıçta her ne kadar şahsi fikirleri unutturucu, ülkenin kurtulușu amacında birleşmiş olsa da, doğaldır ki, milletin kendi mukadderatını kendi eline alması kavramını somutlaştıran "Saltanatın Kaldırılması" eylemi gerçekleşmiştir. Bundan sonra milli hâkimiyete uygunluk, şeriata uygunluk kavramının yerini doldurmuştur. ${ }^{4}$ Özellikle Milli Mücadele esnasında, dini görüşlerin halk üzerindeki etkilerinin ne denli olumsuz olabileceği görülmüştür. Bu nedenle millet, hâkimiyetine ortak kabul etmemesi gereğini anlamış, başka bir deyişle laiklik süreci "Milli Hâkimiyet" kavramı ile başlamıştır. Hilafetin kaldırılması da bu gerekliliğin bir ürünüdür. Asırlardan sonra Türk milleti, dinin siyasi aktörlüğünün zararlarını idrak etmiştir. ${ }^{6}$ Nitekim CHF, 9 Eylül 1923 tarihinde "Parti itikat ve vicdaniyat meselelerini politikadan kurtarmayı ... devlet ve millet islerinde din ve dünyayı tamamıyla birbirinden ayırmayı en önemli ilkelerden sayar" cümlesini nizamnamesine koymuştur. ${ }^{7}$ Bağımsız Türkiye Cumhuriyeti'nin ilanından henüz dört ay sonra, 1 Mart 1924'te, Mustafa Kemal konu hakkında şunları söylemiştir:

“Bağlılıkla mutlu bulunduğumuz İslam dinini, astrlardan beri devamedegeldiği gibi bir siyaset aracı olma hatasından temizlemek ve yüceltmek gereği ... Kutsal ve ilahi olan inançlarımızı, belirsiz ve kararsız olan her türlü çıkar ve tutkuların ortaya çıtı̆̆g siyasetlerden ve siyasetin bütün kollarından bir an önce ve kesinlikle kurtarmak, milletin dünya ve ahiret mutluluğu gereğidir."

Bundan sonraki süreçteki gelişmeler hep laiklik yönünde olmuştur. Laikliğe giden yolda ${ }^{9}$ devlet, hukuk, eğitim, yaşam ve kültür alanında

${ }^{4}$ Tarık Zafer Tunaya, İslamcılık Cereyanı, Siyaset İlmi Serisi, Baha Matbaası, İstanbul 1962, s. 147-148.

$5 \mathrm{Bu}$, "Önce, egemenliğin temeli laikleştirildi" cümlesi ile de ifade edilebilir. Bkz. Turhan Feyzioğlu, "Türk İnkılabının Temel Taşı: Laiklik", Atatürk Yolu, Otomarsan Kültür Yayını, İstanbul 1981, s. 195.

${ }^{6}$ Laiklik kavramının 'yerli ve milli' olduğunu vurgulayan Tunaya, Türk kurtuluş mücadelesi esnasında işgalcilerle işbirliğinin din adına yürütüldüğünü, İstiklal için savaşanların tutucu çevreyi saf dışı bırakmak için doğal tedbirler aldı̆̆ını, bu bakımdan laikliğin, başka ülkelerde var diye, onlara benzeme çabası olmadığını; aksine bir savaş ilkesi olduğunu söylemiștir. Bkz Tarık Zafer Tunaya, Siyasi Müesseseler ve Anayasa Hukuku, 3. Bask1, İstanbul Üniversitesi Hukuk Fakültesi Yayını, İstanbul 1972, s. 262.

${ }_{7}$ Gotthard Jaschke, Yeni Türkiye'de İslamlık, Çev. Hayrullah Örs, 1. Baskı, Bilgi yayınevi, Ankara 1962, s. 96.

${ }_{8}$ Atatürk'ün Söylev ve Demeçleri, Bugünkü Dille Yay. Haz. Ali Sevim, İzzet Öztoprak, Akif Tural, Atatürk Araştırma Merkezi Yayını, Ankara 2006, s. 594. Mustafa Kemal'in din anlayışıının basitleştirilmiş, saf ve temiz bir din olduğu söylenebilir.

${ }_{9}$ Karal, Laiklik devriminin, diğer Türk İnkılâplarının temeli olduğu ve bütün inkılâpların genel özelliğini taşıdığını belirtir. Karal'a göre laiklik, "İnkılâbın kurduğu bütün yeni müesseselere ve getirdiği yeni zihniyete hâkim bir unsurdur.” Bkz. Enver Ziya Karal, "Devrim ve Laiklik, Laiklik 1, Osman Yalçın Matbaası, İstanbul 1954, s. 68; Aynı hususta Ozankaya şöyle demiştir: “..Bütün çağdaşlaşma atılımlarının temelinde, ruhunda laik dünya toplum ve insan anlayışı yatar. Bu atılımların hepsi, bir yönü ile laikliğin gerçekleşmesi için başvurulmuş, bir yönü ile de laikliğin gerçekleşmesinin sonucunda mümkün olmuş ya da 
yenilikler yapmıștır (Şeriye ve Evkaf Vekaleti'nin kaldırılması, Tevhid-i Tedrisat Kanunu, Tekke ve Zaviyelerin kapatılması, bazı unvanların kullanımının yasaklanması). Ardından laikliğe doğru, özellikle gelenekleri ortadan kaldırarak çağdaşlaşma çizgisine ulaşmak amacıyla adımlar atılmıştır. Bunlar, laikliği gerçekleştirme yolunda izlenen tutumun "Milli Hâkimiyet" kavramından "Çăğdaşlaşma" kavramına geçişini de ifade eder. Kılık kıyafet, dil ve yazı, Türk Medeni Kanunu gibi reformlar, dinin en etkin yayılma imkânı bulduğu geleneksi yapıy ${ }^{10}$ değiştirirken, bir yandan da laiklik aşamasını etkin kılmıştır. Özellikle 4 Ekim 1926 tarihinde kabul edilen Türk Medeni Kanunu, dinsel medeni hukuku kaldırmış ve aile, miras, mülkiyet, borç gibi sosyal hayatı düzenleyen eşitliğe dayalı bir sistem getirmiştir. Böylece laiklik anlayışı gündelik hayata da aksedilerek sürecin önemli bir aşaması da aşılmıştır. Nitekim 1927 yılına gelindiğinde, Türkiye Cumhuriyeti büyük oranda dinsel özelliklerinden arındırılmıştır. Laikliğe geçiş çabaları sürecinde dinin siyasi rolü bir kez daha tecrübe edilmiş; halkın bazı kesimlerinin dini istismar eden feodal ağalar ya da siyasi aktörler tarafından kolaylıkla galeyana getirildiği görülmüsstür (Terakkiperver Cumhuriyet Fırkası'nın kuruluşu, Şeyh Sait Olayı, İzmir Suikastı gibi). Laikliğe geçiş sürecini tamamlamak amaciyla 10 Nisan 1928 tarihinde Anayasa'dan “Türkiye Devleti'nin dini İslam'dır” ifadesi çıkarılarak, milletvekili ve cumhurbaşkanının yemin etmeleri ile ilgili dinsel içerikli cümleler kaldırılmıştır. Böylece kuruluşundan beş yıl sonra Türkiye Cumhuriyeti, Laik Devlet sürecine başlamıştır.

\section{Türkiye'de Laikliğin Anlamı}

1931 yılında CHF temel ilkeleri arasına giren Laiklik prensibi, 10 Mayıs 1931 tarihli CHF Üçüncü Büyük Kurultayı'nda "Fırka, devlet idaresinde bütün kanunların, nizamların ve usullerin, ilim ve fenlerin muasir medeniyete temin ettiğ i esas ve şekillere ve dünya ihtiyaçlarına göre yapılmasını ve tatbik edilmesini prensip olarak kabul etmiştir. Din telakkisi vicdani olduğundan, firka din fikirlerini devlet ve dünya işlerinden ve siyasetten ayrı tutmay milletimizin muasır telakkisinde başlıca muvaffakiyet amili görür." ${ }^{\prime l}$ şeklinde ifade edilmiştir. Nitekim Atatürk'ün ölümünden önce laikliğin ulaştığı son nokta olan 1937'deki meclis görüşmelerinde İçişleri Bakanı Şükrü Kaya, Türkiye'de laikliğin anlamını açıkça ifade edecektir:

" Mademki tarihte deterministiz, mademki icraatta pragmatik maddiyetçiyiz, o halde kendi kanunlarımızı kendimiz yapmalıyız. Kendi cemaatimizi maverayı dünyaya taalluk eden her türlü endişelerden, her türlü lahuti hayallerden müberra olarak

laiklik ilkesinin kılavuzluğunda yürütülmüştür.” Bkz. Özer Ozankaya, Atatürk ve Laiklik, Türkiye İş Bankası Kültür Yayınları, 1. Baskı, Ankara 1981, s. 259.

${ }^{10}$ Berkes, age, s. 28-29.

${ }^{11}$ Tarih IV, Devlet Matbaası, İstanbul 1934, s. 188. 
kanunlarımızı, bugünün icaplarını, maddi zaruretlerini göz önünde tutarak yapmalıyı. Memleketin maddi hayatı ancak bu surette kurtulur. (Memleketin) Maneviyatı için Türk'ün temiz ahlakını inkişaf ettirmek kafidir."

"Biz diyoruz ki dinler, vicdanlarda ve mabedlerde kalsın. Maddi hayat ve dünya işlerine karışmasin." 12

$\mathrm{Bu}$ ifadelerden, Türkiye'deki laiklik anlayışının sadece din ve vicdan özgürlüğünden ibaret olmadığı, gerektiğinde sosyal hayata müdahale eden aktif bir esasa dayanma gereği açıkça anlaşılmaktadır. ${ }^{13}$ Bu manada laiklik anlayışı, dine karşı olmak amacında değil; aksine dinin sosyal ve siyasal hayatta kişisel emellerce kullanılmasını engellemek amacındadır. Bu anlayış, bireylerin her türlü konuya çözümü dinde araması ve din aracılarının elinde köleleşmesi yerine, bilim ışı̆̆ında kendi aklını kullanmasını hedefler. Bireyin ve toplumun manevi hayatı için Türk ahlakını meydana çıkarmayı yeterli görür. Bu laiklik anlayışı, çoğu Müslüman olan Türk toplumuna siyasi ve sosyal hayatta yaşanan, milli hâkimiyet ve çağdaşlaşma emellerine engel sorunlar neticesinde ${ }^{34}$ yerleşmiş, tarihi tecrübelerin doğurduğ $u^{15}$ yerli ve milli ${ }^{16}$ bir laiklik anlayışıdır. Bu bakımdan bir devrim olarak laiklik pasif kalamaz. ${ }^{17}$

${ }^{12}$ TBMMZC, Devre 5, İctima 2, Cilt 16, s. 61.

${ }^{13} \mathrm{Bu}$ konuda Tunaya (İslamcılık Cereyanı, s. 183) şunları söylemiștir: Türkiye'de hiçbir zaman din ile devletin mutlak ayrılığı olmamış̧ır. Din, devletin amme hizmeti olarak benimsediği bir konudur. Siyasi iktidar tarihi tecrübelerin 1şı̆̆ı altında, dini suistimalden korumak ve dini çevrelerin siyasi ve sosyal vesayetini önlemek gayesiyle din işlerini kontrol altında tutmuştur." Aynı konuda Karpat, "Din üzerine konulan tahditlerin sebebi dine karşı içten içe beslenen bir düșmanlık değildi. İslamiyeti kontrol altında tutmak reformların toplumda kökleşmesine imkân vermek için görülen acil ihtiyaçtan doğmuştu" demektedir. Bkz. Kemal Karpat, Türk Demokrasi Tarihi, Istanbul Matbaası, Istanbul 1967, s. 246.

${ }_{14}$ İslam dininin, dünya işlerinin saçaklı birçok dalına hükmedecek yeterli ve sabit kurallar koymadığı açıktır. Bu durum, adli, hukuki, siyasi, sosyal, ekonomik birçok alanda şahsi fikirlere göre değişen çok başlılı̆̆a neden olmuştur. Bkz. Prof. Dr. Neşet Çağatay, "Laiklik ve Din İlişkileri”, Atatürk Düşünncesinde Din ve Laiklik", Atatürk Araştırma Merkezi Yayını, Ankara 1999, s. 99.

${ }^{15}$ Atatürk, Türk milletine has devrimlerin gereğini şöyle açıklar: "Biz ilhamlarımızı gökten ve gaipten değil; doğrudan doğruya hayattan almış bulunuyoruz. Bizim yolumuzu çizen, içinde yaşadığımız yurt, bağrından çıktığımız Türk milleti ve bir de milletler tarihinin bin bir facia ve 1zdırap kaydeden yapraklarından çıardığımız neticedir" Bkz. Atatürk’ün Söylev ve Demeçleri, s. 860. Nitekim, 1937'de “Altı Ok"un Anayasaya alınma görüşmelerinde (TBMMZC, aynı tutanak, s. 67) Kütahya Mebusu Recep Peker, Türkiye'deki Laiklik anlayışının özgünlüğünü şu sözleri ile ifade etmiştir: "Arkadaşlar, laiklik telakkisinin de yalnız nazari hayatta değil; bilhassa tatbiki sahada da Türkiye'de olan derinlik ve samimilik ile tatbik edildiği yer, dünyada yok denebilir. Laisizmi ilim ve politika mevzuu olarak ilk telaffuz eden insan kütleleri, bunların bugünkü devlet şekilleri içinde bile bizde olduğu kadar incelik ve ciddiyetle takip edildiği yer yoktur."

${ }^{16}$ Tunaya'nın yorumu. Bkz. Bülent Tanör, "Prof. Dr. Tarık Zafer Tunaya'nın Anayasal Gelişme Tezi", Tarık Zafer Tunaya'ya Armağan, İstanbul Barosu Yayını, Istanbul 1992, s. 24.

${ }^{17} \mathrm{Bu}$ hususta Ozankaya (age, s. 78), şunları söylemiştir: "Laiklik, en sık yinelenen 'dinle devletin birbirinden ayrı olması' tanımının yüzeysel olarak anlaşılmasına dayalı 'din alanında kim ne yaparsa yapsın, devlet karışamaz' anlamını taşımaz.” Berkes ise (age, s. 450) 


\section{Türkiye’deki Laiklik Anlayıșı'nda Büyük Kırılma (1945-1948)}

Türkiye'deki laiklik anlayışının 1945 yılına kadar herhangi bir sıkıntı yaşamadığı anlaşılmaktadır. Fakat 1945 yılına gelindiğinde CHP içerisindeki bir grubun, dinde yapılacak reformlara karşı olduğu görülmüştür. Bu grup, laikliğin temellerini daha da kökleştirici bir girişim olarak ilerici olan CHP Meclis Müstakil Grubu'nun bazı önerilerini reddetmiștir. Bunlar kısaca, “devlet-din işlerini ayırmış olan bir rejimde Diyanet İsleri Başkanlığı'nın kaldırılmasını, bunun yerine dil kurumuna benzer bir teşkilatın ikame edilmesini; Kuran ve din tatbikatının öz Türkçe olarak tanzim ve tertibini; ibadet yerlerinin Türk'ün geleneklerine uygun bir tarza konularak halkevlerinin ibadet yeri, ibadet yerlerinin de halkevlerine benzer bir şekle

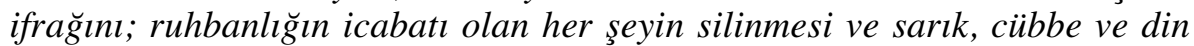
tatbikatında kullanılan her türlü kıyafetin ilgasını; ibadet usul ve zamanlarının düzenlenmesini" 18 içeriyordu. Bu önerilere itiraz eden grup, dinde reforma karşı olmadıklarını; ancak reformların devlet tarafından yapılmasının laikliğe aykırı olduğu ve dindeki reformun doğal gelişim çerçevesinde kendiliğinden olması gerektiğini savunmuştur. Laikliğin kurucusu CHP içerisindeki bu iki farklı görüş, Türkiye'deki laiklik anlayışının, parti mensuplarının tamamınca net anlaşılmamış olduğunu göstermiştir. Nitekim bu görüş ayrılığ 1 , Atatürk'ün ölümünden yedi yıl sonra, Türkiye'deki laiklik devriminin pasifize edilmeye başlanmasının ilk örneğini ortaya koymuştur.

II. Dünya Savaşı sonrası Soğuk Savaş döneminde Amerika'da olduğu gibi Türkiye'de de komünizm aleyhtarlığı artmıştır. İlerici olan, dinde reformu savunan her fikir komünistlikle suçlanmıştır. Gericilik ise antikomünist cephede durarak siyasete ve topluma doğru akacak mecra bulmuştur. Bunun yanı sıra savaş yıkıntısının doğurduğu maddi hoşnutsuzluğa karşı dünyevi ihtiyaçları unutturacak bir faktöre de ihtiyaç duyulmuştur. ${ }^{19}$ Ekonomik buhranın yarattığı tepkiler ahlakın bozulduğu, din duygusunun zayıfladığı yönünde değerlendirilmiştir. Bir anlamda ilerici görüşlere ve maddi yıkımın doğurduğu ekonomik sıkıntıdan doğan itirazlara karşı din, panzehir olarak kullanılmıştır. Kimi yazarlarca ahlaksızlığın arttığı

bu düşünceyi savunanlar için "Laiklik adına din özgürlüğü tezini ileri süren akımların çoğu, dinsel olmaktan çıkıp siyasal bir nitelik alır." demiştir.

${ }_{18}$ CHP Büyük Kurultayı'nın 10 Mayıs 1946 Olağanüstü Toplantısına Sunulan CHP Müstakil Grubu Raporu ve Ekleri, TBMM Basımevi, Ankara 1946, s. 355-356.

${ }^{19}$ Feroz Ahmad, gerici fikirlerin yayılma sahalarını şu şekilde değerlendirmiştir: "Rasyonalizm ve bilimsel düsünce, güçlü bir şekilde kök salması asırlar alan ve esenliğ i bakımından değişik sosyo-ekonomik unsurların varlığına gerek duyan narin bitkilerdir. Bütün ilerlemelere rağmen uyku halinde olan tehdit ya da gerici fikirler her zaman mevcuttur ve kriz ve bozulma dönemlerinde meydana çkar gibi olurlar" Bkz. Feroz Ahmad, "Türkiye'de Kemalizm ve Siyasetin Laikleşmesi”, Atatürk'ün Düşünce ve Uygulamalarının Evrensel Boyutları, 2-6 Kasım 1981 Uluslararası Sempozyum, Ankara Üniversitesi Yayını, s. 45. 
yönünde yazılar yazılmış, bu yolla toplumda baskı unsuru oluşturulmuştur. ${ }^{20}$ Buna rağmen çok partili hayata geçildikten sonra dahi, yeni kurulan partiler, parti programlarında ve söylemlerinde laiklik ilkesinin muhafazasından söz etmeye itina göstermiştir. ${ }^{21}$ Nitekim Demokrat Parti Başkanı Celal Bayar, 1946 seçimlerinden önce propaganda faaliyeti olarak halka dağıtılan beyannamelerinde dikkat edilecek hususu şu şekilde açıklama gereği duymuştur:

“... Ancak bu gibi beyannamelerde parti programı çerçevesinden dişarı çıkılmaması, programın metin ve ruhuna aykırı tefsirlere yer verilmemesi ve bilhassa nezaket ve ehemmiyeti izaha lüzum göstermeyecek kadar açı olan laiklik meselesinden asla bahsedilmemesi...,22

“... Şurası katî ve açık, açık surette bilinmelidir ki, her türlü çalışmalarımızda dinden ve dolayısıyla laiklikten bahsetmek memleket ve partimiz aleyhine zarar verebilir..."23

Kuşkusuz bu tavırda Türk siyasi hayatının Terakkiperver Cumhuriyet Fırkası, Serbest Fırka gibi örnekleri ile İstiklal Mahkemeleri, Takriri Sükun Kanunu deneyimlerinin payı büyüktür.

1947 yılında ise CHP Yedinci Büyük Kongresi'nde Devletçilik ve Laiklik, üzerinde en çok tartışılan konu olmuştur. Laiklik kavramının yeniden gözden geçirilmesi ifade edilerek büyük tartışmalar yaşanmıştır. CHP içerisindeki "gelenekçi cephe", "Türkiye’de hurafeler anlaşıllp inkllâp benimsenmiş olduğuna göre, Milli Ĕ̈itim Bakanlı̆̆ı'nca tanzim edilecek bir programla ilk okullarda çocuklarımıza dini esaslar hakkında bilgi vermenin

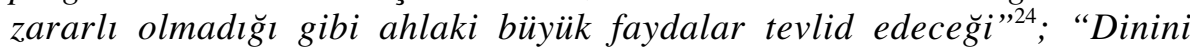
kuvvetlendiren milletler daima sosyal tekamüle mazhar olmuş, payidar olmuştur; ihmal edenler ise geri kalmışlardır", "Bütün ahlaksızlık ve fenalıklar, dinimizin ihmal edilmesinden ileri geldiği için önergenin kabulï"25; "Dinsiz bir milletin memleketinde hiçbir korku kalmaz, yaşayabilmesi için bir mefhumdan korkusu olmalıdır", "Diyanet İşleri Riyasetini bütün kadrosuyla devlet kadrosundan çıkararak ecdadımızın bu dini yürütmek için vakfetmiş oldukları paraların bütün varlığını toplayan Vakıflar İdaresi'nin başına geçirilmesi" "26; "İnsanlık, fert olarak, cemiyet

\footnotetext{
${ }^{20}$ Bu yazılar hakkında bkz. Jaschke, age, s. 98-102; Karpat, age, s. 236-237.

${ }^{21}$ İnönü'nün Demokrat Parti'nin programında "İtikad-1 diniyeye biz hürmetkarız" gibi bir maddenin olmamasını, partinin kurulma şartlarından biri olarak gördüğü anlaşılmaktadır. Bkz. Metin Heper, İsmet Inönü, Çev. Sermet Yalçın, Tarih Vakfı Yurt Yayınları, İstanbul 1999, s. 166.

${ }^{22}$ Celal Bayar'ın Söylev ve Demeçleri 1946-1950, c. V, Haz. Özel Şahingiray, Ankara 1956, s. 433-434.

${ }^{23}$ Age, s. 446-447.

${ }^{24}$ Vehbi Dayıbaş'ın konuşması, CHP Yedinci Büyük Kurultayı, Ankara 1948, s. 448.

${ }^{25}$ Abdulkadir Güney'in konuşması, age, s. 449, 450.

${ }^{26}$ Sinan Tekelioğlu'nun konuşması, age, s. 450, 451.
} 
olarak, millet olarak dinin manevi bağlarına sarılmak mecburiyetindedir... Biz bu ihtiyacı İslam dininin kabul ettiği ahlak kanunlarında bulacă̆ız”, "Gençliğin muhtaç olduğu manevi gıdayı tattırmak için mekteplerimizde din dersi okutulmalıdır... Dinden korkmayalım; ben amele arasında yayılan kızıl tohumların neşvünemasından korkarım"27; "Türk milletinin bünyesinden doğmayan Medeni Kanun'u kabul ederken acaba nazım rolünü oynayacă̆ını nereden ve hangi mantı̆̆ın sinesinden çıkardılar?", "Devlet varsa, Hükümet varsa, mahkemelerimiz ve ordu varsa ne irtica, ne de gayya kuyusu vardır... Diyanet İşleri'nin devlet teşkilatı arasından çıkarılarak muhtar bir idare şekli verilmesi", ; "Laisizm bizim icadımız mıdır?... Laik Türk Devleti koskoca bir maziye istinad ediyor, onun için çok kuvvetlidir, tehlikede değildir.. Telaşa lüzum yok, inkılabımız yıkılmaz... Milletler, milliyet dini ile Rus komünizmine karşı mücadele halindedir... Mazlum milletler, mahkum milletler son müdafaalarını, kendi tarihimize bakını, din teşkilatlarıyla yapmaktadırlar... Komünizm bir din olarak intişar ettiği için her yerde din adamlarını takip ediyor...", "Bugünkü Türk toprakları içerisinde koyu, korkunç irticayı tutacak bir tek münevver yoktur. O halde asgarinin asgarisi olarak laik devletlerde yapılanın onda biri kadar Türk milletine dini müesseselerde hizmet edecek adamlart yetiştirelim.."29 şeklindeki ifadelerle Türkiye'deki laiklik uygulamasının sert ve gerçek laikliğe aykırı olduğu yönündeki görüşlerini öne sürmüşlerdir.

$\mathrm{Bu}$ görüşlere karşı söz alan diğer milletvekilleri ise, "Esasen dünyanın hiçbir yerinde laiklik anlayışı kendisinin anladı̆̆ (Tanrıöver'in) manadaki laiklik anlayışı değildir. Türk milletinin son bekası ne dinde ne imandadır. Türk'ün kendi vicdanı ile Allah arasındadır. Türk'ün son kuvveti kendi damarlarındaki asil kandadır.", "Eski laiklik anlayışımızda sabit olalım. Onu komünizm aleyhtarlı̆̆ ile karıştırmayalım. Komünizm iktisadi bir meslektir; ona iktisadi delillerle cevap verilir. Benim amelem aç iken, ben amelemi din ile tatmin edemem. Ben lükse gittiğim zaman amele din yolunda olduğum için bana müzahir olamaz. Yedinci kurultayımızın Hamdullah Suphi Tanrı̈̈ver'i bu mu olacaktı?”, "Bizim laiklik teşkilatımız asla din düşmanlığı ile başlamamıştır... Biz laiklikten neyi kastediyoruz? Allah ile kul arasındaki mevzu tamamen ferde istinad etmektedir... Komünistliğe karşı dinin bir mücadele vasıtası olarak kabul edileceğini sanmıyorum", "Din, Allah ile kul arasında hususi bir hesaplaşma işidir. Ben müteyeddin bir adamım, çocuğumun da öyle yetişmesini isterim. Fakat, diş tehlike karşısında ben aradı̆̆ım kuvveti kalbimin âsil kanında buluyorum." ${ }^{30}$; "Dünya uleması birleşmişler, insan camiasının bir akideye bağlanmasını kabul etmişlerdir. Onlar bunda da müttefiktirler. Akideye bağlanmak

\footnotetext{
${ }^{27}$ Şükrü Nayman'ın konuşması, age, s. 451, 452.

${ }^{28}$ Ėmin Karpuzoğlu'nun konuşması, age, s. 453, 454.

${ }^{29}$ Hamdullah Suphi Tanrı̈̈ver'in konuşması, age, s. 454-458, 469.

${ }^{30}$ Cemil Barlas'ın konuşması, age, s. 459-460.
} 
herhalde ruhun manevi bir kuvveti, bir zevkidir. Insana ferah verir, inkişaf verir. Lakin, o akideye bağlananların, o insanların kültürlü, bilgili, seviyesi, ilmi görüşü yüksek olması şarttır. Bunsuz olan insanlar, hurafata kaçarlar. $O$ vakit akide değil, softalık olur. İste bugün kurmak istediğimiz laiklik, tam bir akide esasına bağlanmıştır", "Arkadaşlar, bizim en ziyade çektiğimiz dert ve bela, istibdadın maarifi söndürmesindendir.." 31 ; "Biz Müslüman dininin mü'miniyiz. Fakat örümcekli kafaların çorbaya çevirdiği ukalalıklar ve efsaneler manzumesinin de o nisbette aleyhtartyız. Ayakta kalmamizın tek şartı olan medeniyet imkan ve icaplarından 'Gavur icadıdır' diye bizi yıllarca alıkoyan kara taassub, kızıl emperyalizm kadar, düsmanımız. Ben milletimin en büyük düşmanlarını düşününce, kızll gözlerini memleketime diken şimal tehlikesi ile birlikte aziz Kubilay'ın başını mızrağa takan kara ruhu da aynı kinle hatırlyorum. Biz, bu kara taassubun bir kene gibi milletin dimağına ve tefekkürüne yapışmasına son vermek için laikliği almışız.”, "Ruhu alabildiğine Türk, düşüncesi alabildiğine Garpli bir millet olmayınca, ayakta kalmamızın, yaşamamızın imkanı yoktur; onun için devletçe laikiz.", Her devrin kendine mahsus yaşama şartları içinde taazzuv eden bir ahlak telakkisi vardır ve olacaktır. Asırlar boyunca tekrar israr eden irtica, din irticaldır. Sinsi girer, sonra bütün inkılap nesillerine 31 Mart faciası hazırlar." ${ }^{32}$ görüşlerini ifade etmişlerdir.

CHP Yedinci Büyük Kurultayı, gelenekçi cephenin tekliflerini reddetmiştir; fakat çok partili hayatın Türk siyasi hayatına getireceği yeni anlayış ve uygulamaların arifesinde yaşanan bu tartışmalar, laiklik gibi hassas bir konuda net bir ayrışmaya sahne olmuştur. Gelenekçi cephe, devletin din ile ilgili bir kurumu bünyesinde barındırmasının laikliğe aykırı olduğundan, milletin yaşaması için dinsiz olamayacağından ${ }^{33}$, dinden korkması ve ona bağlı olması gerektiğinden ${ }^{34}$, inkılapların yerleştiği ve dinin artık tehlike olmadığından dinin komünizmi engelleyeceğine ${ }^{35^{3}}$ kadar varan

${ }^{31}$ Ali Rıza Esen'in konuşması, age, s. 461.

${ }^{32}$ Behçet Kemal Çağlar'ın konuşması, age, s. 462-463.

${ }^{33}$ Laikliği, Atatürk devrimlerinin can damarı olarak nitelendiren Heper, bu hakkında şunları söylemiştir: "Din işleri ile dünya işlerini birbiri ile karıştırmamaya, kısaca laiklik denilirse, laiklik elbette dinsizlik değildir. Ancak dünya işlerinin arkasında hep tanrının ya da elçisinin buyruklarını bulmaya alışmış bir kimse, bu ayırmayı kolay anlayamaz. Kutsallıktan arınmış bir dünya ile birdenbire uzlaşamaz. Meydana gelen boşluğu kendi aklıyla doldurmak, dinden kaynaklanan hazır açılama ve davranıs semaları yerine kendi usavurumlarını koymak zorundadır. Bunu da aydınlanmış, özgür kişiliği olanlar başarabilir.” Metin Heper, agm, s. 328-329.

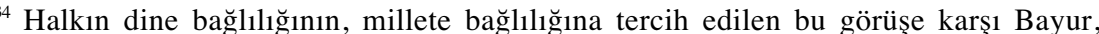
"Mukaddesata bağlılıktan çok söz ediliyor. Bizce mukaddesatın başında Türk millet ve devleti gelir. Onları yok olmaktan kurtarıp dipdiri tutan devrimlerimiz de mukaddesattandır. Her ulussever ve yurtsever Türk, onlara candan bağlı kalmalıdır." demiştir. Bkz. Yusuf Hikmet Bayur, "Laiklik", Laiklik 1, s. 20.

35 Bu iddia, 8-10 Haziran 1949 tarihleri arasında TBMM'de Laiklik tartıșmaları sırasında Fuat Köprülü tarafından da savunulacaktır. Bkz. Jaschke, age, s. 102. Nitekim 1949'dan itibaren yaygınlaşan bu düşünce neticesinde, çoğu siyasi parti tarafından sol 
iddialarla Türk milletine has laiklik anlayışının aşındırılması yoluna gitmişlerdir. Nitekim Türkiye'de laiklik devrimini anlamış karşı görüş ise, CHP gibi devrimci bir parti için bu husustaki anlayış değişikliğinin Türkiye'nin çağdaşlaşması hedefine engel olacağını, bu nedenle laiklik anlayışının muhafaza edilmesi gereğini, Türkiye'deki laiklik anlayışının Türk milletinin ihtiyaçlarından doğduğunu, ilmi yüksek olmayan cahil toplumda dinin hurafelere kaçacağını ve bunun engellenemeyeceğini ifade ederek, laikliği aşındırma girişimine nispeten engel olmuşlardır.

Yeni kurulan partilerin kapatılma korkuları nedeniyle laiklik ilkesine bağlılıklarına rağmen CHP, 1947 yılından itibaren din konusunda beklenmedik bir açılıma gitmiştir ve din faktörünü siyasete taşımıştır. $\mathrm{Bu}$ açılım hakkında CHP, laikliği sulandırma çabalarını meşru göstermek için bazı argümanlar kullanmıştır:

1- Devrimler artık yerleşmiştir.

2- Halk olgunlaşmıştır.

3- Çok partili bir rejimde halkın istekleri göz ardı edilemez.

1947 yılından itibaren artık CHP'nin dine karşı tutumu ve izlediği siyaseti, bu argümanlara dayanarak değişmiştir. İsmet İnönü, 1948 yılı başında ilkokullarda ders saati dışında seçmeli din dersi verilmesi, Milli Eğitim Bakanlığı'na bağlı imam ve hatip yetiştirecek okullar açılması ve ilahiyat fakültesi kurulması fikrinin kendisinde artık olgunlaştığını söyleyerek, "Şeriat bir sistemdir: Arap harfleri ile, medrese ile, kllık klyafet ile, hukuku ile dini siyaseti ile. Bu sistemin canlanmasina imkan yoktur. 25 senelik bir zaman geçmiştir. Yeni tertiple on sene geçtikten sonra bütün bunun en uzak ihtimallerde kuvvetlerini bile kaybederler.", "Atatürk devrine dönemeyiz. Vatandaş hakkını istediği gibi kullanacaktır. Prensiplerimize halel gelmemek üzere din meselesinin hal zarureti vardır. 25 senelik mesafe aldık, şimdi bunları konuşabiliyoruz. 10 sene de böyle gideriz, mesele kendiliğinden halledilmiş olur, irtica korkusu kalmaz..."36 demiştir. İnönü'nün değişen siyasetinin temelinde, çok partili hayatta iktidar olma isteği yatar; nitekim İnönü, bunu kendisi de söylemiştir: "Demokraside kör inadın, kör taassubun yeri olamaz. Laisizm prensibi mahfuz kalmak üzere moral ihtiyaçlara cevap verecek duruma bir an evvel gelmek, memlekette geniş bir ferahlık ve sempati havası estirecektir. Bunu, bu hükümet

akımlara karşı savunma tedbiri kisvesi altında "dinde liberalizasyon" başlamıştır. Oysa Türkiye, İslamiyet’ten uzaklaşma değil; laikliği gerektiği kadar sağlam bir zemine oturtamamıs olma tehlikesi içindeydi. Bkz. Karpat, age, s. 245. 882 .

${ }^{36}$ Faik Ahmet Barutçu, Siyasi Hatıralar, c. II, 21. yy Yayınları, Ankara 2001, s. 880, 
kaçırmamalıdır. Muhalefetin de sinsi bir silahını elinden düşürmüş̧ olacă̆ız." ${ }^{37}$

CHP'nin değişen politikass ${ }^{38}$ gereği, Milli Eğitim Bakanlığ 1947 yılında, okul dışı din eğitimi için bazı yeni temel ilkeleri kabul etmiştir. 1948 'de Hacca gideceklere devlet tarafından döviz sağlanmıştır. ${ }^{39} 1949$ ' da okullara seçmeli din dersi konulmuş, bazı türbeler açılmıştır. Aynı yıl Ankara İlahiyat Fakültesi açılmıştır. 1950'de İmam Hatip Kursları okullara dönüştürülmüşşür. ${ }^{40}$ CHP'nin din konusunda yaptığı bu yeni açılımlar ${ }^{41}$, din konusundaki tutumları nedeni ile kapatılmaktan korkan yeni kurulan partileri cesaretlendirmiştir. Nitekim kuruluşunda böyle bir amaç göze çarpmasa da DP, büyük oranda CHP'nin din açılımından güç almış; iktidar kaygısı taşıdı $\breve{g}_{1}$ dönemlerde daha da artarak, propaganda araçlarına ve siyasi faaliyetlerine dini işleri dahil etmiştir. Bu bağlamda çok partili hayatta yeni kurulan partiler, din hususunda yeni açılımlar yapan CHP'nin açtığı yolu sadece genişletmiştir.

Demokrat Parti, Mayıs 1950'de iktidarı CHP'nin elinden aldığı zaman İnönü, daha önceki öngörülerinin aksine halkın olgunlaşmadığı ve devrimlerin yerleşmediğini itiraf edecektir: "Kitlenin kabahati yoktur... Son zamanlarda onları yendiğimizi sanıyorduk. Aldanmışı. (Bu netice) dahili politikanın ittihamıdır. Çünkü bu parti fırsatı kurtarmıyor. Inkılaplar salmamıştır. Çok düşman kazanmıştır.." "42 Inönü’nün bu itirafı, seçim öncesi din açılımı yapmak için öne sürülen "halk olgunlaşmıştır, devrimler yerleşmiştir” argümanının yanlışlığını göstermek bir yana, aynı zamanda laiklik prensibinin tahrip edilme gerekçesini de açılar.

\footnotetext{
${ }^{37}$ Barutçu, age, s. 882 .

${ }^{38}$ Değişen bu politikanın Türkiye'ye ne gibi zararlar getireceğini öngören aydınlardan birisi de edebiyatçı Yaşar Nabi' dir. Nabi, daha 1948 yılının başlarında "Geleneklere bağlılı̆̆ın faziletlerinden bahsedenlerin sözlerine körü körüne kapılmamak gereğini” vurgulayarak, "Milli hayatımızla hiçbir ilişkisi bulunmayan sonradan edinme gelenekleri, gerçeklerden ayırt etmekte hassas davranalım" demiștir. Özellikle CHP Yedinci Büyük Kurultayı'nı iyi bir şekilde analiz ederek "İrtica' ya dikkat" diye uyarıda bulunan Nabi, "Hurafeler peşinde hayal avcılığına çıkanları bırakalım, miskinlik tekkelerinde afyonlarını tek başlarına çeksinler", "Bugün geçici sebeplerden ileri gelen türlü sıkıntılarımız ne olursa olsun, bunlardan inkılap prensiplerini mesul göstermek isteyeceklerin oyununa kapılmamaya, fırsat düşkünlerine fırsat vermemeye çok dikkat etmeliyiz" demiştir. Bkz. Yaşar Nabi, Nereye Gidiyoruz?, Varlık Yayınları, İstanbul 1948, s. 120-121.

${ }_{39}$ Yaşar Nabi (age, s. 114), Hac'dan dönenlerin büyük kısmının şapkasız geldiğine dikkat çekerek, "Şüphesiz bunlara şapka giymenin küfür olduğu telkin edilmişti” demektedir. 2004, s. 99 .

${ }^{40}$ SSerif Mardin, Türkiye'de Din ve Siyaset, 10. Baskı, İletişim Yayınları, İstanbul

${ }^{41}$ CHP'nin bu açılımları, seçimlerde CHP'ye oy vermenin günah olmadı̆̆ına dair Müftü'den fetva alıp köylerde yayınlamaya kadar varmıştır. Bkz. Barutçu, age, s. 1007.

${ }^{42}$ Barutçu; age, s. 993.
} 


\section{SONUC}

Mustafa Kemal 1927 yılında CHF İkinci Büyük Kongresi'nde okuduğu Büyük Nutuk'unda “Bunca yüzylllar olduğu gibi, bugün de, milletin cahilliğinden ve bă̆nazlı ğından yararlanarak bin bir siyasi ve şahsi maksatla çıkar sağlamak için din, alet ve vasita olarak kullanmak teșebbüsünde bulunanların memleket içinde ve dışında var olușu, ne yazık ki, daha bizi bu konuda söz söylemekten allkoyamıyor. Insanlık dünyasında din konusundaki uzmanlık ve derin bilgi, her türlü hurafeden arınarak gerçek bilim ve tekniğin ışıları ile tertemiz ve mükemmel oluncaya kadar din oyunu aktörlerine her yerde rastlanacaktır." ${ }^{43}$ demiştir. Anlaşılacağı üzere, siyasi, sosyal, teknik, ekonomik bütün ilerlemelere rağmen, kimi zamanlar uyku halinde olsa bile din, siyasete ve sosyal hayata müdahale etme isteğinden vazgeçmeyecek bir tehdit olarak her zaman mevcuttur. ${ }^{44} \mathrm{Bu}$, devletin dine müdahale etme gereğini de açıklar. Bu bakımdan bir devrim olarak Türkiye'de laiklik anlayışı, devletin dine müdahale etmemesi değil; aksine onu etkisiz ve sınırlı bir alana sokması anlamını taşır. Buna göre sınırsız olarak dinsel ve bireysel özgürlüğün yaşandığı tek yer vicdandır; bunlar, sosyal hayata sıçradığı zaman medeni hukuk kanunları ile sınırlandırılır. Bundaki amaç, aklın her türlü baskıdan uzak olarak hür düşünebilmesini sağlamak esasına dayanır. Nitekim "Hayatta en hakiki mürşit, ilimdir" ifadesi, sadece teknik olarak anlaşılmayıp sosyal hayat için de değerlendirilmelidir. Bu değerlendirme, Türkiye'deki laiklik anlayışının "günlük hayatın her yönünü rasyonelleştirmek zorunluluğu" ${ }^{45} \operatorname{taşıdığını~}$ gösterir. Milletin manevi tatmini ise milli ahlak ile sağlanmalıdır. $\mathrm{Bu}$ bakımdan Türkiye'de, Atatürk'ün anladığg laikliğin sadece yirmi yıl yaşandığı söylenebilir.

Türk siyasi hayatında laiklik ilkesinin tahrip edilmesinin Demokrat Parti ile başladığı gibi yaygın bir görüş vardır; lakin bu tahribat, CHP tarafından başlatılmıştır. Türkiye' deki laiklik anlayışının içsel ve dışsal olmak üzere ekonomik buhran, çok partili hayata geçiş ve dünyadaki antikomünist rüzgar gibi nedenlerle bozulmaya başladığı görülmektedir. CHP içerisinde, Atatürk'ün ölümünden 7 yıl sonra başlayan laiklik konusundaki fikir ayrılığı, CHP Yedinci Büyük Kurultayı'nda doruğa

${ }^{43}$ Mustafa Kemal Atatürk, Nutuk, Bugünkü Dille Yay. Haz. Zeynep Korkmaz, Atatürk Araştırma Merkezi Yayını, Ankara 1999, s. 479.

${ }^{44}$ Feroz Ahmad (agm, s. 46), dünyadaki en ileri derecede sanayileşmiş, zengin bilimsel ve laik geleneği olan Amerika'da bile irticai tehdidin mevcut olduğunu belirterek, hümanizm ve rasyonalizmin o denli kök salmadığı Türkiye'de böylesi bir gerileyişin yıkıcı olacağ öngörüsünde bulunmuştur.

${ }^{45}$ Feroz Ahmad'e göre (agm, s. 44), "En kamusaldan en özele, devletten ekonomiye, evlilik ilişkilerine, aileye ve hatta kişisel dostluklara kadar toplumun her yanını etkileyen bir süreç” Laiklik demektir. Heper (agm, s. 304), Atatürk'ün 'Aydınlanma' kavramını şöyle niteler: "Yaşama, aklın kılavuzluk etmesi, yaşama dayanak olacak değer ve normların akılla bulunması, gelenek-göreneklerin aklın eleştirisinden geçirilmesi ..." 
ulaşmıştır. Laikliğin kurucusu CHP'ye mensup bazı milletvekilleri tarafından milletin dinden mahrum olduğu ve ahlakın bozulduğu gibi iddialarla dini eğitimin gerekli olduğu vurgulanmıştır. Yalnız bu tartışmalarda dikkati çeken, dinin komünizm tehdidine karşı kullanılmak istenmesidir. Bu bakımdan Soğuk Savaş dönemi Türkiye'deki antikomünizm rüzgarının, gericiler için büyük bir fırsat doğurduğu görülmektedir. Teyakkuz halindeki gelenekçi fikirler bu rüzgardan yararlanarak siyasisosyal bütün alanlara yerleşmeye başlamıştır. Ayrıca savaş yıllarının verdiği kıtlık neticesinde tahrik edilen kitlelere karşı din, dünyevi ihtiyaçları söndürücü, sıkıntıları unutturucu bir faktör olarak kullanılmak istenmiştir. İktidar partisi olan CHP, devrimlerin olgunlaştı ğı için irtica tehdidinin olmadığı ve çok partili hayatta halkın isteklerini göz ardı edemeyeceği gibi argümanlar ile Atatürk devrine dönülemeyeceğini savunarak laiklikten tavizlerin yolunu açmıştır. Bu yol, daha sonra yeni kurulan partilerce genişletilmiştir.

Atatürk'ün, dini hurafelerden arındırmak yolunda, onu aklın ve bilimin 1şıkları ile bezemek gereği ile XX. yüzyılda İslamiyet'e en büyük hizmeti yaptığ $1^{46}$ idrak edilememiştir. 1945 yılından itibaren başlayan, laiklik prensibini aşındırma girişimi amacına ulaşmıştır. Bu bakımdan Türkiye'de Atatürk'ün anladı̆̆ laiklik anlayışı, evrensel laiklik anlayışına uymadı̆̆ı gerekçesi ile henüz olgunlaşmamış bir toplumda önce durağanlaşmış, sonra gerilemiştir. Bu, 1928-1948 yılları arası Türkiye'deki laiklik anlayışının medcezir manzarasıdır.

\section{KAYNAKÇA}

ATATÜRK, Mustafa Kemal, Nutuk, Bugünkü Dille Yay. Haz. Zeynep Korkmaz, Atatürk Araştırma Merkezi Yayını, Ankara 1999.

Atatürk'ün Söylev ve Demeçleri, Bugünkü Dille Yay. Haz. Ali Sevim, İzzet Öztoprak, Akif Tural, Atatürk Araştırma Merkezi Yayını, Ankara 2006.

AHMAD, Feroz, “Türkiye'de Kemalizm ve Siyasetin Laikleşmesi”, Atatürk'ün Düşünce ve Uygulamalarının Evrensel Boyutları, 2-6 Kasım 1981 Uluslararası Sempozyum, Ankara Üniversitesi Yayını, Ankara 1981.

BARKAN, Ömer Lütfi, “Türkiye'de Din ve Devlet İlişkileri”, Cumhuriyetin 50. Yıldönümü Semineri, Türk Tarih Kurumu Yayını, Ankara 1975.

BARUTÇU, Faik Ahmet, Siyasi Hatıralar, c. II, 21 . yy Yayınları, Ankara 2001.

BAYUR, Yusuf Hikmet, "Laiklik”, Laiklik 1, s. 20.

\footnotetext{
${ }^{46}$ Bosnalı yaşlı bir din adamının söylediğinden aktaran Feyzioğlu, agm., s. 224.
} 
BERKES, Niyazi, Türkiye'de Çağdaşlaşma, 2. Baskı, Yay. Haz. Ahmet Kumaş, Yapı Kredi Yayınları, İstanbul 2002.

Celal Bayar'ın Söylev ve Demeçleri 1946-1950, c. V, Haz. Özel Şahingiray, Ankara 1956.

CHP Büyük Kurultayı'nın 10 Mayıs 1946 Olağanüstü Toplantısına Sunulan CHP Müstakil Grubu Raporu ve Ekleri, TBMM Basımevi, Ankara 1946.

CHP Yedinci Büyük Kurultayı, Ankara 1948, s. 448.

ÇAĞATAY, Neşet, "Laiklik ve Din İlişkileri”, Atatürk Düşüncesinde Din ve Laiklik", Atatürk Araştırma Merkezi Yayını, Ankara 1999.

FEYZİOĞLU, Turhan, “Türk İnkılabının Temel Taşı: Laiklik”, Atatürk Yolu, Otomarsan Kültür Yayını, İstanbul 1981.

GÖKBERK, Macit, Felsefe Tarihi, 17. Baskı, Bilgi Kitabevi, İstanbul 2007.

HEPER, Metin, “Aydınlanma Felsefesi, Devrimler ve Atatürk”, Çağdaş Düşüncenin Işı̆̆ında Atatürk, 2. Baskı, Dr. Nejat F. Eczacıbaşı Vakfı Yayınları, İstanbul 1986.

HEPER, Metin, İsmet İnönü, Çev. Sermet Yalçın, Tarih Vakfı Yurt Yayınları, İstanbul 1999.

JASCHKE, Gotthard, Yeni Türkiye'de İslamlık, Çev. Hayrullah Örs, 1. Baskı, Bilgi yayınevi, Ankara 1962.

KARAL, Enver Ziya, “Devrim ve Laiklik”, Laiklik 1, Osman Yalçın Matbaası, İstanbul 1954.

KARPAT, Kemal, Türk Demokrasi Tarihi, İstanbul Matbaası, İstanbul 1967.

MARDİN, Şerif, Türkiye'de Din ve Siyaset, 10. Baskı, İletişim Yayınları, İstanbul 2004.

NABİ, Yaşar, Nereye Gidiyoruz?, Varlık Yayınları, İstanbul 1948.

OZANKAYA, Özer, Atatürk ve Laiklik, Türkiye İş Bankası Kültür Yayınları, 1. Bask1, Ankara 1981.

Tarih IV, Devlet Matbaası, İstanbul 1934, s. 188.

TBMM Zabit Cerideleri, Devre 5, İctima 2, Cilt 16, s. 61.

TANÖR, Bülent, "Prof. Dr. Tarık Zafer Tunaya'nın Anayasal Gelişme Tezi”, Tarık Zafer Tunaya’ya Armağan, İstanbul Barosu Yayını, İstanbul 1992.

TUNAYA, Tarık Zafer, İslamcılık Cereyanı, Siyaset İlmi Serisi, Baha Matbaası, İstanbul 1962.

TUNAYA, Tarık Zafer, Siyasi Müesseseler ve Anayasa Hukuku, 3. Baskı, İstanbul Üniversitesi Hukuk Fakültesi Yayını, İstanbul 1972. 